Jan Paweł Strumiłowski OCist ${ }^{1}$

Uniwersytet Papieski Jana Pawła II w Krakowie

\title{
Egzystencjalna aplikacja dogmatu na przykładzie Thomasa Mertona
}

Doświadczanie Boga przez mistyków niejednokrotnie wydaje się doświadczeniem na pozór oderwanym od rzeczywistości. Często twierdzi się o mistykach, że w momentach spotkania z Bogiem zostają oni jakby wyrwani z tego świata po to, by doświadczać Boga bezpośrednio. I rzeczywiście w pewnym sensie takie twierdzenie jest prawdziwe. Mistyk w swoim doświadczeniu faktycznie bardzo intensywnie doświadcza Boga - tak intensywnie, że doświadczenie rzeczywistości otaczającej go może wydawać się zanikać pod naporem spotkania Kogoś, kto tę rzeczywistość absolutnie przekracza. Niemniej jednak doświadczenie Boga, które dyskredytuje stworzenie i jego pośrednictwo epifanijne, $\mathrm{z}$ dogmatycznego punktu widzenia wydaje się nieprawdziwe. Ekstaza mistyczna jest jednym ze szczytowych momentów na drodze do poznania Boga. Wynika ona jednakże z prostego wzrostu życia wiary ${ }^{2}$, która pozwala, zgodnie z podstawowymi dogmatami katolickimi, doświadczyć Boga, nie tra-

1 Jan Strumiłowski, dr, ur. 1983 w Pyskowicach, w 2005 roku wstąpił do opactwa zakonu cysterskiego w Jędrzejowie. W 2015 roku obronił doktorat na Uniwersytecie Papieskim Jana Pawła II w Krakowie na podstawie rozprawy Soteriologiczny wymiar piękna w teologii XX wieku.

Por. J. W. Gogola, Teologia komunii z Bogiem, Kraków 2001, s. 252. 
cąc niczego z własnego człowieczeństwa - czyli nie tracąc też ludzkiego sposobu doświadczania.

Temat doświadczenia religijnego oraz egzystencjalnego wymiaru wiary stał się szczególnie ważny i obecny w teologii współczesnej. Właściwie niemal cały wiek XX w teologii naznaczony jest zwrotem antropologicznym, który kładzie mocny akcent na wymiar ludzkiej percepcji i przeżycia wiary. Poszczególne „wielkie teologie” ubiegłego wieku, chociaż bardzo mocno naznaczone są znamieniem egzystencjalnym, to jednak w swojej istocie, mimo swojego silnego ukierunkowania antropologicznego, są wciąż w dużej mierze budowanymi w oparciu o objawienie konstruktami intelektualnymi. Ich wielka wartość oczywiście nie ulega przez to pomniejszeniu. Niemniej jednak w kontekście obecnie panującego klimatu uprawiania teologii bardzo wartościowe mogą okazać się poszukiwania ciążące ku teologii wypływającej bezpośrednio z doświadczenia Boga - które, jak wiadomo, przekracza możliwości ludzkiego intelektu. Tego typu teologią jest tzw. teologia monastycz$\mathrm{na}^{3}$, a jednym z jej wybitych przedstawicieli w ubiegłym wieku był Thomas Merton.

Niniejszy artykuł jest próbą rekonstrukcji metateologicznej struktury rozumienia prawd wiary przez Thomasa Mertona w kontekście współczesnego, egzystencjalnego charakteru teologii w celu odczytania w tymże kluczu jego interpretacji dwóch podstawowych dogmatów, jakimi są dogmat o Trójcy Świętej i dogmat o wcieleniu. Tak dokonana prezentacja stanowić ma egzemplifikację relacji między treścią wiary a jej doświadczeniem, która jest relacją zwrotną i wzajemną.

\section{Ortodoksja i ortopraksja u Mertona}

W osobie i życiu tego wielkiego mnicha odnajdujemy znamienny przykład mistycznego doświadczania Boga zapośredniczonego w świecie stworzonym. Jego pisma są świadectwem świadomości zaistnienia błędu, pole-

3 Por. W. H. Shannon, Milczaca lampa, tłum. A. Wojtasik, P. Ducher, Bydgoszcz-Lublin 2002, s. 249. 
gającego na twardym rozgraniczeniu dziedzin teologicznych dotyczących teorii (dogmatyka) od tych, które są świadectwem praktyki (duchowość/ mistyka). Niezrozumienie źródeł tego podziału może prowadzić do fatalnych skutków, czyniąc z dogmatów hermetyczne i czysto teoretyczne sformułowania, kompletnie nieprzystające do ludzkiej egzystencji. Tymczasem ojcowie Kościoła, precyzyjnie formułując definicje wiary, byli świadomi, że ich praca nie jest intelektualną gimnastyką, ale ma służyć chrześcijańskiej praxis ${ }^{4}$. Ta świadomość też pozwalała Mertonowi właściwie ustawiać relacje między ortodoksją i ortopraksją. Dogmaty interesowały go bowiem przede wszystkim w swoim wymiarze praktycznym, czyli o tyle, o ile wpływały na konkretny kształt życia duchowego ${ }^{6}$.

W myśl powyższych założeń warto przypomnieć, że zdogmatyzowana nauka orzekająca o o n to lo gi i Boga powstawała na kanwie intelektualnej refleksji nad e ko no $\mathrm{m}$ ią zbawienia. Taki proces został zainicjowany dzięki zetknięciu się chrześcijaństwa z filozofią grecką ${ }^{7}$ Teologia, jako zrodzona z takich źródeł, nie jest jedynie wyabstrahowaną teorią, ale już przez swoją naturę istnienia "na styku” ma ona prowadzić poprzez przyjęcie „prawdy” do spotkania z Bogiem

Dzięki temu, że Merton zwykł nie tylko poddawać teologicznej interpretacji swoje codzienne doświadczenie wiary, ale także spisywać je w swoich dziennikachi książkach poświęconych tematyce kontemplacji', dla lepszego zrozumienia dynamiki dogmatów możemy spróbować, na podstawie jego pism, nakreślić teorię doktrynalnych, tzn. teologicznych podstaw umożliwiających spotkanie z Bogiem. Zadanie to jest o tyle ważne, że na pierwszy rzut oka wydaje się, jakoby absolutna transcendencja Boga sprawiała, że nie istnieje żaden byt, który by Boga przypominał. Prawdy tej przecież strzeże

\footnotetext{
4 Por. T. Merton, Doświadczenie wewnętrzne, tłum. I. i P. Zarębscy, Kraków 2005, s. 80n.

5 Por. T. Merton, Nowy posiew kontemplacji, tłum. L. Zielińska, Kraków 2005, s. 245.

6 Por. M. B. Pennington, Thomas Merton-brat, mnich, tłum. E. Nartowska, Bydgoszcz 1999, s. 149.

Por. T. Dzidek, Granice rozumu w teologicznym poznaniu Boga, Kraków 2001, s. 185-193.

Por. P. Ogórek, Mistyka według Tomasza Mertona, Warszawa 1996, s. 180n.

Oprócz systematycznego spisywania i dokonywania teologicznej interpretacji swojego doświadczenia wiary Merton podejmował także próbę systematycznej refleksji dogmatycznej dotyczącej doświadczenia wiary (por. T. Merton, Znak Jonasza, tłum. K. Poborska, Poznań 2001, s. 169).
} 
stwierdzenie Soboru Laterańskiego IV, wedle którego „pomiędzy Stwórcą a stworzeniem nie można dopatrzeć się tak wielkiego podobieństwa, żeby nie trzeba było widzieć większej pomiędzy nimi różnicy" ${ }^{10}$. Między naturą Boga a naturami stworzeń istnieje zatem przepaśćc ${ }^{11}$. Natomiast natura pośrednia, mogąca stanowić pewnego rodzaju continuum scalające rzeczywistości Boską i ludzką, według chrześcijańskiej wizji świata nie istnieje ${ }^{12}$. Taka wizja rzeczywistości uwzględniającej istnienie przepaści ontologicznej wbrew pozorom nie wyklucza jednak poznania Boga na drodze kontemplacji stworzeń. Co więcej, dogmaty taką możliwość nie tylko zakładają, ale same w sobie jej strzegą i w pewnym sensie ją opisują.

Fakt epifanii pełni prawdy bożej w Chrystusie jest podstawą tego procesu. Wyrażenie Bożego objawienia w tak bliskich i zrozumiałych nam kategoriach jak konkretne, ludzkie istnienie Chrystusa w pełni sankcjonuje przeniesienie uwagi z ekonomii na ontologię lub, dokładniej mówiąc, sankcjonuje odczytywanie ontologii w ekonomii ${ }^{13}$. We współczesnej teologii zasada ta została dowartościowana przez Karla Rahnera, który na nowo wydobył prawdę dotyczącą orzekania o „Bogu immanentnym” ze względu na Jego ścisłą identyczność z Bogiem działającym w ekonomii Zbawienia ${ }^{14}$. Ponadto ta współzależność wyznacza także relację między wiarą podmiotową i przedmiotową, tzn. określa i uzasadnia, że fides quae creditur, stanowiąc depozyt prawd, jednocześnie wzbudza fides qua creditur, czyli sam akt wiary. A ten z kolei, jak zwrócił na to uwagę Joseph Ratzinger, jest osobowym fenomenem wiążącym z Chrystusem jako Logosem, stanowiącym najwyższą realność w człowieku ${ }^{15}$. Na ścisły związek tych dwóch znaczeń zawartych w słowie „wiara” - który pośrednio stanowi

10 Sobór Laterański IV, Konstytucja 2 „O błędzie opata Joachima”, 2, 7, [w:] Dokumenty Soborów Powszechnych: tekst grecki, łaciński, polski. Tom 2: Konstantynopol IV, Lateran I, Lateran II, Lateran III, Lateran IV, Lyon I, Lyon II, Vienne (869-1312), układ i oprac. A. Baron, H. Pietras, Kraków 2007.

11 Por. W. Johnston, Mistycyzm Obłoku niewiedzy, tłum. A. Gical, Poznań 2001, s. 8.

12 Por. F. M. Dermine, Mistycy i wizjonerzy. Twarza w twarz z niewidzialnym światem, tłum. A. Mrozek, Warszawa 2006, s. 263.

13 Por. T. Dzidek, Granice rozumu w teologicznym poznaniu Boga, dz. cyt., s. 210.

14 Por. K. Rahner, Teologia i antropologia, [w:] K. Rahner, Pisma wybrane, t. 1, tłum. G. Bubel, Kraków 2005, s. 47.

15 Por. K. Góźdź, Logosowy charakter wiary według Josepha Ratzingera-Benedykta XVI, „Polonia Sacra” 17 (2013) nr 2 (33), s. 44. 
istotę tegoż artykułu - zwraca się współcześnie uwagę również w dokumentach Kościoła, czego świadectwem jest encyklika papieża Franciszka Lumen fidei. Papież, chociaż nie określa tradycyjnymi formułami tych dwóch znaczeń „wiary”, nawiązując do Ewangelii według św. Jana, wydobywa obydwa znaczenia i wiąże je z Osobą Chrystusa, wskazując na samo źródło tego powiązania. Nie można przecież wierzyć w Chrystusa, nie wierząc Chrystusowi. A wierzyć w Jezusa jest aktem wiary, natomiast wierzyć Jezusowi to znaczy dobrowolnie przyjąć Jego naukę ${ }^{16}$.

Poniżej zostanie zatem zaprezentowana (na podstawie pism Mertona) próba analitycznej rekonstrukcji dogmatu trynitarnego i chrystologicznego, z uwzględnieniem nade wszystko egzystencjalnego znaczenia tych prawd wiary.

\section{Tajemnica Trójcy Świętej w dynamice poznania i miłości}

Z punktu widzenia filozofii i teologii chrześcijańskiej tylko Bóg jest zdolny do poznania własnej istoty ${ }^{17}$. Między Trójjedynym a stworzeniem istnieje metafizyczna przepaść, lecz w obrębie samej Trójcy odbywa się doskonałe i nieskończone poznanie i miłowanie ${ }^{18}$. To wewnątrzboskie odkrywanie własnej istoty jest tak doniosłe, że poprzez nie dokonuje się pochodzenie Osób Boskich ${ }^{19}$. Początkiem tej koncepcji jest teza, wedle której „Bóg, który jest nieskończoną inteligencją, kontempluje swoją Prawdę w Lustrze Myśli, która jest jednocześnie tożsama z Jego Substancją i Naturą"20. Powstający w ten sposób obraz własnej istoty w umyśle Ojca jest z Nim tożsamy pod każdym względem, wyjąwszy związek synostwa ${ }^{21}$. Zatem Syn jest niczym innym, jak doskonałą myślą Ojca o samym sobie ${ }^{22}$.

16 Por. H. Sławiński, Oryginalne ujęcie kwestii wiary w encyklice papieża Franciszka „Lumen fidei”, „Polonia Sacra” 17 (2013) nr 2 (33), s. 99n.

17 Por. T. Merton, Chleb na pustyni, tłum. S. Sumiński, Kraków 1996, s. 84n.

18 Por. T. Merton, Chleb na pustyni, dz. cyt., s. 85.

19 Por. T. Merton, Chleb na pustyni, dz. cyt., s. 85.

20 T. Merton, Wspinaczka ku prawdzie, tłum. P. Parlej, Kraków 2008, s. 324.

21 Por. T. Merton, Wspinaczka ku prawdzie, dz. cyt., s. 324.

22 Por. T. Merton, Siedmiopiętrowa góra, tłum. M. Morstin-Górska, Poznań 1998, s. 450. 
Merton oczywiście nie jest autorem powyższej koncepcji. Zaczerpnął ją od św. Tomasza z Akwinu. W teologii Doktora Anielskiego proces tworzenia wewnętrznego obrazu, który jest tak doskonały, że nie brakuje mu nawet realnego istnienia, jest nazywany rodzeniem ${ }^{23}$. Polega ono według Akwinaty na kontemplacji własnej istoty przez Boga, który w tymże akcie ogarnia całego siebie myślą. Powstały obrazjest współistotny Myślącemu, tzn. „posiada tę samą naturę, gdyż w Bogu myśleć i istnieć stanowi jedno”24. Współistotność ta opiera się więc na fakcie pochodzenia w e w nę tr z n e go, jaki prezentuje działanie samego umysłu, gdyż skutek myślenia zawsze w całości pozostaje w podmiocie myślącym ${ }^{25}$.

Teoria ta pozwala wysnuć dwie ważne konkluzje dotyczące poznania Boga. Po pierwsze, wewnętrzny charakter rodzenia przedstawionego jako akt umysłu tłumaczy istnienie Syna w Ojcu, zapobiegając przy tym pokusie zniesienia realnej odrębności Osób - myśl jest bowiem zawsze w relacji do umysłu, nawet w przypadku autorefleksji, kiedy to sam umysł jest treścią myśli. Poznanie konnaturalne, z jakim mamy tutaj do czynienia, nie zakłada tożsamości Osób (substancji), a jedynie zgodność natur. Poznać Boga może zatem taka osoba, która cieszy się udziałem w Jego naturze. Po drugie, tożsamość myślenia i istnienia w Bogu stoi na straży współistotności Syna z Ojcem, zjednoczonych w jednej naturze, dzięki czemu w Boskiej istocie nie ma żadnego rozdźwięku ${ }^{26}$. Poznanie w Bogu zatem jest poznaniem egzystencjalnym, dotyczącym nie tylko pewnej władzy czy sfery, ale ogarniającym całą istotę. Innymi słowy, w Bogu „poznać” znaczy tyle samo, co „współistnieć” i „być zjednoczonym”. Poznanie Boga nie może więc sprowadzać się do poznania dyskursywnego. Dogmaty nie dają nam przystępu do poznania Boga, o ile zatrzymujemy się na samej ich analizie intelektualnej. Poznaniu Boga odpowiada bardziej poznanie intuicyjne, gdyż sam Bóg poznaje wszystko w jednym prostym oglądzie ${ }^{27}$.

23 Por. św. Tomasz z Akwinu, Suma teologiczna. O Trójcy Przenajświętszej, tłum. P. Bełch, Londyn 1978, I, q. 27, a. 2, [dalej: STh].

24 STh I, q. 27, a. 2.

25 Zob. STh I, q. 27, a. 1.

26 Por. T. Merton, Nowy człowiek, tłum. P. Ciesielski, Kraków 1996, s. 116.

27 Por. P. Lichacz, M. Olszewski, M. Przanowski, Wstęp, [w:] św. Tomasz z Akwinu, O poznaniu Boga, Kraków 2005, s. 28. 
Jeszcze bardziej egzystencjalne znaczenie ma druga część dogmatu trynitarnego, mówiąca o pochodzeniu Ducha Świętego. Ojciec kontemplujący Syna całą swoją istotą kocha Go. Ta egzystencjalna Miłość, doskonale współistotna Ojcu, jest Osobą Ducha, która wespół z Ojcem i Synem tworzy jedno wspólne odkrywanie własnej rzeczywistości ${ }^{28}$. Duch Święty jest więc Miłością skierowaną ku poznawanemu Synowi, wypływającą z jednej natury Boskiej ${ }^{29}$. Dopełniając ten obraz myślą św. Tomasza: „[...] według czynności woli staje się [w Bogu] jeszcze inne pochodzenie, mianowicie pochodzenie Miłości, dzięki czemu byt miłowany jest w podmiocie miłującym”30. Zaznaczyć tutaj trzeba, że „chociaż w Bogu umysł nie jest czymś innym od woli" ${ }^{31}$, to jednak „,nie może być mowy o pochodzeniu Miłości, jeśli się nie uwzględni uprzedniego pochodzenia Słowa. Wola bowiem może kochać to tylko, co wpierw umysł począł" ${ }^{32}$, dlatego też „w Bogu pochodzenie miłości i pochodzenie Słowa układają się między sobą z zachowaniem odrębności”" ${ }^{33}$.

Trójca Święta jest zatem nieustanną wymianą miłości, która w swoim nadmiarze jest wzajemnym udzielaniem siebie, stanowiąc swoisty puls samooddania wewnątrztrynitarnego ${ }^{34}$. Bóg określony takim dogmatem jest przeciwieństwem doskonałej, lecz samotnej monady. W swojej istocie jest On komunią Osób połączonych wspólną zasadą, którą jest miłość te Osoby przenikająca ${ }^{35}$.

Wzmocnienie egzystencjalnego znaczenia podkreśla w tym kontekście prawda, według której z tak skonstruowanej teologii Trójcy możemy wywnioskować, że sam Bóg żyje według pewnej zasady, którą jest miłość. A jeśli to prawo jest prawem Stwórcy, to dotyczy ono i obowiązuje także człowieka - nie jako zewnętrzny nakaz, ale tak jak to jest w samym Bogu - jako immanentna zasada rządząca światem i człowiekiem ${ }^{36}$.

\footnotetext{
28 Por. T. Merton, Chleb na pustyni, dz. cyt., s. 85.

29 Por. T. Merton, Siedmiopiętrowa góra, dz. cyt., s. 450.

30 STh I, q. 27, a. 3.

STh I, q. 27, a. 3.

STh I, q. 27, a. 3.

STh I, q. 27, a. 3.

Por. T. Merton, Posiew kontemplacji, tłum. M. Morstin-Górska, Kraków 1989, s. 38.

Por. T. Merton, Posiew kontemplacji, dz. cyt., s. 37n.

Por. T. Merton, Ostatni z Ojców, tłum. M. Sabiniewicz, Skoczów 2004, s. 73.
} 
To jednak nie wyczerpuje zakresu egzystencjalnej aplikacji dogmatu trynitarnego. Poznanie wyżej opisane dotyczy przecież Trójjedynego Boga, a nie człowieka. Miłość, która jest zasadą życia Trójcy, w świecie stworzonym jest zaledwie odblaskiem wewnątrzboskiej miłości. Pełnia egzystencjalnego znaczenia dogmatu trynitarnego staje się zrozumiała dopiero w zestawieniu jej z treścią dogmatu chrystologicznego. Sam Merton, rozważając znaczenie i treść dogmatu trynitarnego, czynił to zawsze w kontekście chrystologicznym, pozwalającym na odczytanie go w perspektywie antropologiczno-egzystencjalnej.

\section{Tajemnica wcielenia jako fundament epifanii}

Z centralnej dla autora Siedmiopiętrowej góry prawdy wiary, jaką jest tajemnica Trójcy ${ }^{37}$, wynika następna, która swoją doniosłość zawdzięcza nade wszystko faktowi, że to dzięki niej przepaść metafizyczna zostaje przełamana, włączając nas w dynamikę wewnętrznego życia Boga ${ }^{38}$. Drugi aspekt stawiający wcielenie na piedestale ludzkiej egzystencji polega na tym, że ta prawda poprzez swoją właściwość scalającą wszystkie dziedziny ludzkiego życia uzasadnia także pewnego rodzaju „podobieństwo”, na którym zasadza się epifanijność stworzenia, umożliwiająca doświadczenie Boga w świecie i poprzez świat ${ }^{39}$.

Bez objawienia historycznego człowiek byłby zdany jedynie na obserwację natury, z której mocą intelektu mógłby wnioskować coś o jej Twórcy.Jednakże nawet w takim przypadku możliwość rozpoznania Stwórcy z obserwacji stworzeń odnajduje swoje podłoże w pewnego rodzaju Bożym oświeceniu przyrodzonego umysłu. Klasyczna teologia to „oświecenie” wpisane w naturę nazywa przyczyną pierwszą, natomiast samą pracę umysłu przyczyną wtórną poznania Boga. Zdolność ludzkiego umysłu do poznania Boga ze stworzeń, jest już wynikiem i jednym ze znamion podobieństwa człowieka

${ }_{37}$ Por. P. Hart, Sylwetka duchowa Thomasa Mertona, [w:] T. Merton, Drogowskazy, tłum. A. Świderkówna, Wrocław 1988, s. 88.

38 Por. P. Hart, Sylwetka duchowa Thomasa Mertona, dz. cyt., s. 88.

39 Por. W. Grzybowski, Kierownictwo duchowe w pismach Tomasza Mertona, [w:] Sztuka kierownictwa duchowego, red. J. Augustyn, J. Kołacz, Kraków 2007, s. 228. 
do Boga, ufundowanego $\mathrm{w}$ akcie stwórczym ${ }^{40}$. Zakres takiego poznania jest jednakże bardzo nikły. Pozwala ono zaledwie na poznanie istnienia Stwórcy, który przewyższa stworzenie ${ }^{41}$. Barierę w pełnym poznaniu stanowi nie tylko transcendencja Boga, ale i sama natura cielesno-duchowa człowieka. Ciało z jednej strony jest narzędziem ekspresji ducha i narzędziem poznania (poprzez zmysły), ale z drugiej strony to samo ciało wyznacza ścisłe ramy epistemologiczne, determinując już sam zakres komunikacji ${ }^{42}$.Z tego właśnie względu człowiek pozostawiony samemu sobie nigdy nie byłby w stanie wyrobić sobie słusznego poglądu na temat natury Boga ${ }^{43}$.

We wcieleniu jednakże został przerzucony swoisty pomost między Bogiem a człowiekiem ${ }^{44}$. Przyjęcie ludzkiej natury zmieniło sytuację epistemologiczną człowieka poprzez zmianę jakości objawienia. Współistotność natur w Chrystusie sprawiła, że historyczna Osoba Jezusa z Nazaretu w pełni pozostając Bogiem i Słowem Boga w każdym wymiarze swojej egzystencji, stała się w pełni człowiekiem ${ }^{45}$. Między dwiema Jego naturami nie ma najmniejszego nawet rozłamu ${ }^{46}$, co oczywiście nie oznacza, że jego ludzka natura stała się tożsama z naturą Boską ${ }^{47}$. Doniosłość zjednoczenia hipostatycznego polega na tym, że dzieła Syna Bożego dokonane w ziemskim życiu w pełni pozostawały czynami Boga ${ }^{48}$. Zjednoczenie natury bożej z naturą ludzką nie zniszczyło tej drugiej, lecz sprawiło, że zaczęła ona należeć do Syna Bożego. Czyli, innymi słowy, w Chrystusie wszystko, co ludzkie, stało się zarazem Boskie, gdyż wszystkie Jego akty, a nawet samo istnienie, są aktami i istnieniem Osoby Boskiej, przez co objawiały Jego istotę tożsamą z Jego wolą ${ }^{49}$. Takie spojrzenie na Osobę Chrystusa jest logiczną konse-

40 Por. Tomasz z Akwinu, Komentarz do „O Trójcy Świętej” Boecjusza, [w:] Tomasz z Akwinu, O poznaniu Boga, tłum. zbiorowe, Kraków 2005, s. 63.

${ }_{41}$ Por. P. P. Lichacz, M. Olszewski, M. Przanowski, Wstęp, dz. cyt., s. 25.

${ }^{42}$ Por. K. Tarnowski, Usłyszeć niewidzialne. Zarys filozofii wiary, Kraków 2005, s. 76.

43 Por. T. Merton, Pokój monastyczny, [w:] T. Merton, Szukanie Boga, tłum. P. Ogórek, Kraków 1983, s. 274.

${ }^{44}$ Por. T. Merton, Doświadczenie wewnętrzne, dz. cyt., s. 94.

45 Por. T. Merton, Wspinaczka ku prawdzie, dz. cyt., s. 324.

46 Por. T. Merton, Doświadczenie wewnętrzne, dz. cyt., s. 84.

47 Por. T. Merton, Posiew kontemplacji, dz. cyt., s. 67.

48 Por. T. Merton, Siedmiopiętrowa góra, dz. cyt., s. 236.

49 Por. T. Merton, Doświadczenie wewnętrzne, dz. cyt., s. 83. 
kwencją dostrzeżenia w Nim podwójnej relacji. Poprzez wcielenie Logos wszedł w wyjątkową relację ze stworzeniem, nie tracąc przy tym absolutnej łączności z Ojcem ${ }^{50}$. Dusza Chrystusa niezmiennie cieszyła się doskonałym wyczuciem swojej łączności z Ojcem ${ }^{51}$. Wizja ta została przysłonięta jedynie podczas męki Zbawiciela ${ }^{52}$, co jednak nie pozwala na wyciągnięcie wniosku, że sama jedność z Ojcem została w tym momencie naruszona. Zatem Chrystus jest tym, w którym możemy poznać istotę Boga, bo w Nim Ojciec ogląda swój majestat, piękno i mądrośćs3. W zestawieniu z powyżej nakreślonym dogmatem trynitarnym widać szczególnie, że w Chrystusie natura Boga została nie tyle opowiedziana, co uobecniona.

Dlatego też nigdy nie wolno nam sprowadzić objawienia do obwieszczenia pewnego rodzaju prawdy ${ }^{54}$. Syn Boży stał się człowiekiem nie w celu wyłożenia doktryny, lecz w celu przeobrażenia natury ludzkiej, dając jej przystęp do Boga ${ }^{55}$. Co więcej, we wcieleniu nie chodzi tylko o Osobę Jezusa, ale o każdego człowieka, ponieważ, jak zauważa Merton, „Bóg stając się człowiekiem, nie stał się jedynie Jezusem Chrystusem, ale też potencjalnie każdym mężczyzną i każdą kobietą, jacy kiedykolwiek istnieli. W Chrystusie Bóg stał się nie tylko «tym» konkretnym człowiekiem, ale też, w szerszym i bardziej mistycznym sensie, jednak nie mniej prawdziwie, «wszystkimi ludźmi»" ${ }^{56}$. I dlatego właśnie ucieleśniony Logos stwarza nam dyspozycję ontyczną umożliwiającą „kontakt” z Bogiem. Nie chodzi tutaj zatem jedynie o objawienie Boga w ludzkich kategoriach, ale też o uzdolnienie do odczytania w tym, co ludzkie, tego, co boskie ${ }^{57}$.

Zatem według trapisty z Getsemani teologia pośrednictwa Chrystusa nie sprowadza się jedynie do wypełnienia metafizycznej nieciągłości,

\footnotetext{
50 Por. T. Merton, O świętym Bernardzie, tłum. E. Dąbrowska, Kraków 2005, s. 15.

51 Por. T. Merton, O świętym Bernardzie, dz. cyt., s. 15.

52 Szerzej to zagadnienie opracowuje przyjaciel Mertona, Jacques Maritain (zob.J. Maritain, Łaska i człowieczeństwo Jezusa, tłum. A. Ziernicki, Warszawa-Ząbki 2001, s. 25-43 i 117-132).

53 Por. T. Merton, Wspinaczka ku prawdzie, dz. cyt., s. 326.

${ }_{54}$ Por. T. Merton, Wspinaczka ku prawdzie, dz. cyt., s. 329.

55 Por. T. Merton, Wspinaczka ku prawdzie, dz. cyt., s. 20.

56 T. Merton, Nowy posiew kontemplacji, dz. cyt., s. 282; intuicję tę potwierdza Sobór Watykański II: „Syn Boży poprzez Wcielenie zjednoczył się w pewien sposób z każdym człowiekiem" (Sobór Watykański II, konst. Gaudium et spes, 22).

57 Por. J. Skawroń, Noc ducha i dezintegracja pozytywna, Kraków 2007, s. 74.
} 
zaistniałej w sposób konieczny z faktem pojawienia się grzechu, który jest zerwaniem relacji z Bogiem. Fakt wcielenia wprowadza w życie ludzkie rzeczywistość przekraczającą stan pierwotnej szczęśliwości, którą cieszył się Adam. Analizując teksty Nowego Testamentu, Merton zauważa, że także przed stworzeniem Chrystus był już „Kosmicznym Pośrednikiem”, ponieważ wszystko zostało stworzone w Nim, przez Niego i dla Niego. Stworzenie człowieka na Boski obraz i podobieństwo było zaś zapowiedzią i przygotowaniem na przyszłe i pełne zjednoczenie w Chrystusie ${ }^{58}$. Autor Nowego człowieka odwraca dynamikę ekonomii, zakładając, że wcielenie wcale nie musiało być dyktowane następstwem upadku. W jego mniemaniu rzecz ma się dokładnie odwrotnie. W swoich poglądach jest on bardziej zgodny z twierdzeniem Jana Dunsa Szkota, według którego to stworzenie zostało uczynione ze względu na mające dokonać się wcielenie. Argumenty dla swoich twierdzeń Merton odnajduje przede wszystkim w liście do Kolosan ${ }^{59}$ : „[Chrystus] jest obrazem Boga niewidzialnego - Pierworodnym wobec każdego stworzenia, bo w Nim zostało wszystko stworzone: i to, co w niebiosach, i to, co na ziemi. [...] Wszystko przez Niego i dla Niego zostało stworzone [...] i wszystko w Nim ma istnienie" (Kol 1, 15-17). Obraz odmalowany w tym Liście przedstawia Chrystusa jako tego, który był przed Adamem, a w którym dopiero Adam, jak zresztą całe stworzenie, zostało powołane do istnienia. Zatem to Chrystus jest uzasadnieniem, początkiem i celem istnienia wszelkich bytów ${ }^{60}$. Każde stworzenie bierze więc udział w misterium Chrystusa, odznaczając się Jego podobieństwem poprzez egzystowanie w pewnego rodzaju analogii do Niego ${ }^{61}$. Wcielenie ma w takim schemacie charakter iście paradygmatyczny.

Z tak pojętej chrystologii wyłania się ważna zasada antropologiczna: o ile Chrystus jest niestworzonym obrazem Ojca, o tyle my jesteśmy Jego stworzonymi obrazami ${ }^{62}$. Będąc stworzeni w Jego Boskiej Osobie, już

58 Por. J. Skawroń, Noc ducha i dezintegracja pozytywna, dz. cyt., s. 74.

59 Por. J. Skawroń, Noc ducha i dezintegracja pozytywna, dz. cyt., s. 91.

60 Por. T. Merton, Nowy człowiek, dz. cyt., s. 91.

${ }_{61}$ Por. C. Vagaggini, Teologia. Pluralizm teologiczny, tłum. J. Partyka, Kraków 2005, s. 102.

62 Por. T. Merton, Nowy człowiek, dz. cyt., s. 93; podobny pogląd możemy odnaleźć już u pierwszych ojców Kościoła i pisarzy wczesnochrześcijańskich, takich jak Tertulian, Hipo- 
przez samą naturę jesteśmy z Nim zjednoczeni ${ }^{63}$. Dodatkowo, co zauważa Merton, nasze „naturalne” podobieństwo i obraz są wynikiem tego, że Boskie Słowo jest archetypicznym obrazem ludzkiej duszy ${ }^{64}$. Dysponujemy zatem dwiema przesłankami: naszego stworzenia w Chrystusie, które już jest powodem pewnego rodzaju zjednoczenia na gruncie samej natury, i wcielenia, które to pierwotne zjednoczenie nie tylko dopełniło, ale i istotowo umożliwiło u samych jego podstaw. Możemy więc powiedzieć, że Chrystus jest ipso facto „źródłem łaski, dzięki której ta jedność dokonuje się w naszych duszach" "65. Dzięki temu możemy też zgodzić się z wnioskowaniem, wedle którego, jeśli ,jesteśmy stworzeni w Słowie i jesteśmy podtrzymywani przez Nie w każdej chwili, niestworzony Obraz Boga, w Którym żyjemy i mamy swe istnienie, jest zawsze obecny w głębi naszej duszy" "66. Ten Niestworzony Obraz, którym jest sam Bóg przebywający w ludzkiej duszy, jednakowo jest źródłem naszego naturalnego istnienia, jak i życia nadprzyrodzonego ${ }^{67}$.

Doniosłość tego faktu mieści się w tym, że obecność Boskiego Logosu w duszy ludzkiej otwiera przed człowiekiem perspektywę usynowienia, dającą mu przystęp do życia wewnętrznego Trójcy ${ }^{68}$. Taka jedność, przez Mertona identyfikowana z teologiczną wiarą, w swojej pełni nie ma jednak charakteru ontologicznie niezniszczalnego - gdyż mimo że wyrasta z natury, przynależy już do porządku łaski. Przekracza jednakże zwykłą, nawet najpełniejszą zgodę ludzkiego umysłu i woli z Boskim umysłem i wolą. Ma bardziej radykalną jakość: jest związkiem, na mocy którego Chrystus staje się w człowieku zasadą i źródłem Bożego życia udzielającego mu Ducha ${ }^{69}$. Tenże Duch z kolei, upodabniając nas do Syna, pozwala poznać Ojca ${ }^{70}$, a przez to daje nam udział w życiu Trójcy Świę-

lit, Pseudo-Grzegorz z Nyssy, Anastazy Synaita (por. H. U. von Balthasar, Teologia misterium paschalnego, tłum. E. Piotrowski, Kraków 2001, s. 37).

63 Por. T. Merton, Nowy człowiek, dz. cyt., s. 92.

64 Por. T. Merton, Nowy człowiek, dz. cyt., s. 93.

65 T. Merton, Nowy człowiek, dz. cyt., s. 93.

66 T. Merton, Nowy człowiek, dz. cyt., s. 93.

${ }_{67}$ Por. T. Merton, Nowy człowiek, dz. cyt., 94.

68 Por. T. Merton, Nowy posiew kontemplacji, dz. cyt., s. 159.

69 Por. T. Merton, Nowy posiew kontemplacji, dz. cyt., s. 160.

70 Por. T. Merton, Ślub konwersacji, tłum. A. Gomola, Poznań 1997, s. 150. 
tej udzielając nam świętości, piękna i mądrości bożej¹. Dzięki temu nie tylko możemy, patrząc na Chrystusa, ,dowiadywać się” o Ojcu, ale możemy mieć udział w Jego kontemplacji ukierunkowanej ku Ojcu ${ }^{72}$, a to już przekracza nie tylko naturę ludzką, ale przekracza także proste przyjęcie prawd, których umysł ludzki nigdy sam by nie odkrył. Udział i smakowanie jest czymś nieporównanie większym od najdoskonalszego opisu czy informacji. Objawienie w Chrystusie, czego świadectwem są dogmaty, nie tyle obwieszcza nam prawdę, ile przemienia (udoskonala) naturę ludzką, uzdalniając ją do wychylenia (ekstazy) w kierunku Boga.

Jak więc widać, w ujęciu Tomasza Mertona dogmaty nie są jedynie zespołem prawd, na które należy wyrazić zgodę intelektu. Co więcej, zgoda intelektu wydaje się tutaj nawet nie najważniejsza. Dogmaty wiary nie opisują rzeczywistości Boskiej, która miałaby być wyizolowana od doświadczenia egzystencjalnego wierzącego. Ich znaczenia nie można zawężać jedynie do informacji chociażby z tego względu, że objawienie istoty Boga dokonało się na kanwie ekonomii zbawienia. Zatem bardziej trafne jest twierdzenie, że opisują one ludzką egzystencję, odniesioną do Boga i ufundowaną przez Niego już w samym akcie stworzenia, lecz także dopełnioną $\mathrm{w}$ akcie odkupienia. Wierzyć znaczy zatem przyjąć prawdy objawione na sposób całej swojej egzystencji, czyli nie tylko zgodzić się rozumem i wolą, jak domagała się tego chociażby konstytucja Dei filius, ale zgodzić się życiem albo, mówiąc dokładniej, zanurzyć się w tej rzeczywistości, która kryje się za sformułowaniami dogmatycznymi. Wierzyć to znaczy opowiedzieć się za wcielonym Logosem i w pewnym sensie „ujrzeć” Jego rzeczywistość jako tę, która jest podstawą istnienia każdej innej rzeczywistości, nie wyłączając własnej egzystencji³

71 Por. S. T. Zarzycki, Rozwój życia duchowego i afektywność, Lublin 2008, s. 192.

72 Por. T. Merton, 0 świętym Bernardzie, dz. cyt., s. 20.

73 Por. K. Góźdź, Logosowy charakter wiary..., dz. cyt., s. 46. 


\section{Summary}

\section{Egzystencjalna aplikacja dogmatu na przykładzie Thomasa Mertona}

Współczesna teologia kładzie bardzo silny akcent na egzystencjalny wymiar wiary. Wielkie prace teologiczne ubiegłego wieku skupiają się na antropologicznej sferze wiary. Unaoczniają nam to chociażby dokonania takich teologów jak Karl Rahner czy Hans Urs von Balthasar. Teologia bowiem potrzebuje zakorzenienia w ludzkiej egzystencji, gdyż rodzi się ona w wyniku odczytania objawienia konkretyzującego się w życiu ludzkim. Niestety bardzo często dogmaty są traktowane przez katolików jako abstrakcyjne formuły mające niewielki związek z życiem duchowym. Współczesne propozycje teologiczne poprzez zakorzenienie w tzw.zwrocie antropologic znym rzeczywiście zdają się bliższe życiu. Niemniej jednak, pomimo swojego egzystencjalnego ukierunkowania, pozostają one nadal w dużej mierze produktem intelektualnych rozważań. W tym kontekście (dążenia do zespolenia nauki wiary z praktyką życia) bardzo cenna wydaje się teologia mistyków i mistrzów duchowych, którzy nie zajmowali się profesjonalnie tą dziedziną, a jednak dzięki swojemu doświadczeniu duchowemu byli doskonałymi teologami. Jednym z takich mistrzów był Thomas Merton, którego zapiski pokazują, w jaki sposób teologia wyjaśniająca podstawowe dogmaty chrześcijańskie, takie jak dogmat trynitarny i chrystologiczny, może być nie tyle rozważaniem doktrynalnym, ile opisem doświadczenia duchowego. Ponadto tego typu teologia jest bardzo ściśle zharmonizowana z codziennym doświadczeniem świata, przez co może nam pomóc tak przyjmować prawdy wiary, by to przyjęcie prowadziło do głębokiego doświadczenia duchowego.

Słowa kluczowe: dogmat, doświadczenie, egzystencja, mistyka, chrystologia, trynitologia

\section{Existential Application of the Dogmas at the Example of Thomas Merton}

The contemporary theology puts a stress on the existential dimension of the faith. The great theological works of the last century focus on the anthropological aspect of the faith which has been shown by the works of Karl Rahner, Hans Urs von Balthasar and others. The theology does need to have roots in the human existence, for it begins in the reading of the Revelation concretised in the human life. Unfortunately, the dogmas are very often considered by Catholics as abstractive formulas hardly linked with the inner life. The contemporary theological proposals, thanks to some implantation in so-called anthropological turn, seem to be really closer to the life. However, in spite of their existential direction, they remain products of intellectual speculations. In this context (i.e. tendency to join the faith teaching with the practice) the theology of the mystics and spiritual masters seems 
to be very useful since they did not practise the theology professionally but yet were perfect theologians thanks to their experience. T. Merton was one of such masters. His writings show how the theology explaining the fundamental dogmas (like Trinitarian or Christological dogmas) may be not so much a doctrinal investigation as a spiritual experience. Moreover, such theology is very strongly harmonised with the daily experience of the world and that is why it may help us accept the truths of the faith in the way they lead us to a deep spiritual experience.

Keywords: dogma, experience, existence, mysticism, Christology, trinitology

\section{Bibliografia}

Balthasar H. U. von, Teologia misterium paschalnego, tłum. E. Piotrowski, Kraków 2001.

Dermine F. M., Mistycy i wizjonerzy. Twarza w twarz z niewidzialnym światem, tłum. A. Mrozek, Warszawa 2006.

Dzidek T., Granice rozumu w teologicznym poznaniu Boga, Kraków 2001.

Gogola J. W., Teologia komunii z Bogiem, Kraków 2001.

Góźdź K., Logosowy charakter wiary według Josepha Ratzingera - Benedykta XVI, „Polonia Sacra" 17 (2013) nr 2 (33), s. 43-52.

Grzybowski W., Kierownictwo duchowe w pismach Tomasza Mertona, [w:] Sztuka kierownictwa duchowego, red. J. Augustyn, J. Kołacz, Kraków 2007, s. 222-231.

Hart P., Sylwetka duchowa Thomasa Mertona, [w:] T. Merton, Drogowskazy, tłum. A. Świderkówna, Wrocław 1988, s. 85-93.

Johnston W., Mistycyzm Obłoku niewiedzy, tłum. A. Gical, Poznań 2001.

Lichacz P., Olszewski M., Przanowski M., Wstęp, [w:] Tomasz z Akwinu, O poznaniu Boga, tłum. P. Lichacz, M. Olszewski, M. Przanowski, Kraków 2005, s. 5-51.

Maritain J., Łaska i człowieczeństwo Jezusa, tłum. A. Ziernicki, Warszawa-Ząbki 2001. Merton T., Chleb na pustyni, tłum. S. Sumiński, Kraków 1996.

Merton T., Doświadczenie wewnętrzne, tłum. I. i P. Zarębscy, Kraków 2005.

Merton T., Nowy człowiek, tłum. P. Ciesielski, Kraków 1996.

Merton T., Nowy posiew kontemplacji, tłum. L. Zielińska, Kraków 2005.

Merton T., Ostatni z Ojców, tłum. M. Sabiniewicz, Skoczów 2004.

Merton T., Pokój monastyczny, [w:] T. Merton, Szukanie Boga, tłum. P. Ogórek, Kraków 1983.

Merton T., Posiew kontemplacji, tłum. M. Morstin-Górska, Kraków 1989.

Merton T., Siedmiopiętrowa góra, tłum. M. Morstin-Górska, Poznań 1998.

Merton T., Ślub konwersacji, tłum. A. Gomola, Poznań 1997.

Merton T., Wspinaczka ku prawdzie, tłum. P. Parlej, Kraków 2008.

Merton T., Znak Jonasza, tłum. K. Poborska, Poznań 2001.

Ogórek P., Mistyka według Tomasza Mertona, Warszawa 1996.

Pennington M. B., Thomas Merton - brat, mnich, tłum. E. Nartowska, Bydgoszcz 1999.

Rahner K., Teologia i antropologia, [w:] K. Rahner, Pisma wybrane, t. 1, tłum. G. Bubel, Kraków 2005, s. 46-67. 
Shannon W. H., Milczaca lampa, tłum. A. Wojtasik, P. Ducher, Bydgoszcz-Lublin 2002. Skawron J., Noc ducha i dezintegracja pozytywna, Kraków 2007.

Sławiński H., Oryginalne ujęcie kwestii wiary w encyklice papieża Franciszka „Lumen Fidei”, „Polonia Sacra” 17 (2013) nr 2 (33), s. 97-112.

Sobór Laterański IV, Konstytucja 2 „O błędzie opata Joachima”, [w:] Dokumenty Soborów Powszechnych: tekst grecki, łaciński, polski. Tom 2: Konstantynopol IV, Lateran I, Lateran II, Lateran III, Lateran IV, Lyon I, Lyon II, Vienne (869-1312), układ i oprac. A. Baron, H. Pietras, Kraków 2007.

Sobór Watykański II, Konstytucja Gaudium et spes.

Tarnowski K., Usłyszeć niewidzialne. Zarys filozofii wiary, Kraków 2005.

Tomasz z Akwinu, Komentarz do „O Trójcy Świętej” Boecjusza, [w:] Tomasz z Akwinu, O poznaniu Boga, tłum. zbiorowe, Kraków 2005, s. 52-315.

Tomasz z Akwinu, Suma teologiczna. O Trójcy Przenajświętszej, tłum. P. Bełch, Londyn 1978.

Vagaggini C., Teologia. Pluralizm teologiczny, tłum. J. Partyka, Kraków 2005.

Zarzycki S. T., Rozwój życia duchowego i afektywność, Lublin 2008. 